\title{
Research on the Strategies for Improving the Ideological Guidance Ability of College Counselors from the Perspective of Multiple Social Thoughts
}

\author{
Yufei Li*, Chanjuan Li \\ School of Machinery and Automation, Wuhan University of Science and Technology, Wuhan Hubei, China \\ *Corresponding author. Email: liyufei@wust.edu.cn
}

\begin{abstract}
Under the background of multiple social thoughts, it is an important content of ideological and political education in college to enhance the ideological guidance ability of counselors. This paper analyzes the practical significance of strengthening the ideological guidance ability of college counselors, and summarizes the practical difficulties of the ideological guidance ability of college counselors in the aspects of connotation understanding, political theory and professional ability. In this paper, based on the role attribute of counselors to enhance the ability of ideological guidance, based on the professional attribute of counselors to enhance the ability of ideological guidance and based on the systematic attribute of counselors to build up the ability of ideological guidance to put forward the countermeasures to improve the ability of ideological guidance of college counselors under the perspective of multiple social thoughts, this paper provides reference and basis for the construction of college counselors.
\end{abstract}

Keywords: multiple social thoughts, college counselors, ideological guidance ability, promotion

countermeasures

\section{Introduction}

Social thought is the synthesis of thought flow, consciousness flow, idea flow and discourse flow formed under certain historical conditions, so it must keep pace with the change of historical environment, especially the change of economic conditions [1]. College is the forward position of all kinds of ideological and cultural exchange, blend and clash, as well as the forward position of all kinds of social thoughts distribution, debate and struggle [2], social thoughts have an important impact on the construction of campus culture and the world outlook, outlook on life and values of contemporary college students. Counselors are an important part of the teachers and management teams of colleges and universities, they are the backbone of the ideological and political education of college students. Counselors also are the organizers, implementers and mentors of the daily ideological and political education and management of college students, they play an important role in ideological guidance. Therefore, improving the ideological guidance ability of counselors is of great significance to strengthen ideological and political education in college.
2. Starting point: the practical significance of strengthening the ideological guidance ability of college counselors

\subsection{Social thoughts distributed to college}

The information age has expanded and accelerated the spread and speed of various social thoughts, making the influence of multiple social thoughts on politics, economy, culture and other aspects deepen [3]. The openness of college makes them more closely connected with the social environment, and the changes outside the society have a more significant impact on college, the external social thoughts are easy to be distributed to colleges. Due to the lack of certain judgment ability and independent thinking ability of college students, bad social thoughts are easy to spread to college students, which has a bad impact on their emotions, cognition, behavior and other aspects. Therefore, it is particularly important for college counselors to carry out effective ideological guidance for college students.

\subsection{Social issues projected to college}

The generation and development of any social ideological thoughts are closely connected with certain social and historical conditions, and the economic, political, ideological and cultural factors of a certain society are the 
main conditions for the ideological thoughts [4]. Therefore, social ideological thoughts are closely related to social development, and social ideological thoughts that deviate from the mainstream ideological direction of society tend to cause social problems. When social problems such as food safety, house price, employment, education and ecological environment are magnified and distorted, college students show great concern and curiosity, and these problems are easy to project to college. Because college students' thoughts are not mature enough, it will affect their world outlook, outlook on life and values, and then produce wrong understanding and thoughts, which is not conducive to the healthy growth of college students.

\subsection{Social hot spots transmit to college}

In the network information age, there are a large number of non Marxist social thoughts that affect college students to establish correct values [5], which are easy to transmit to college campus. Social hot issues have the characteristics of universality, complex variability, time variability and challenge [6], while college students lack rational analysis and clear understanding, and can not effectively identify the bad thoughts. College counselors are the backbone of ideological and political education for college students, it is urgent for counselors to guide college students to be young Marxists with firm ideals and beliefs, so that college students can correctly understand and discriminate social hot spots.

\subsection{Social contradictions shift to college}

Bad social thoughts are seditious, and some social public events are easily used by bad social thoughts, which intensifies social contradictions, and social contradictions are easily transferred to college. College students in the process of cognition formation are susceptible to the influence and confusion of bad thoughts, affecting the safety and stability of college campuses and social order. As the front-line personnel of students' daily ideological and political education and management, college counselors have the obligation and responsibility to help college students to view social contradictions rationally, analyze social contradictions dialectically, resolve college students' wrong cognition of society, and maintain university development and social stability.

\section{FOCUS:THEPRACTICALDILEMMAOF IDEOLOGICAL GUIDANCE ABLITY OF COLLEGE COUNSELORS}

\subsection{Unclear understanding of the connotation of ideological guidance}

College counselors are mainly engaged in the ideological and political education and daily management of college students. The ideological and political education of students is the most important work content of counselors, and the ability of ideological guidance is the first ability of counselors. At present, some counselors do not understand the nature of their duties clearly, neglect the ideological guidance of college students, and over-emphasize the daily management of students. they have not considered the importance of ideological guidance from the perspective of career height and job requirements. In addition, the effectiveness of ideological guidance of college students has a certain invisibility, which needs a long time to be reflected, it is not as fast as the effectiveness of daily affairs work and the sense of achievement, this leads to the lack of attention of college counselors to the ideological guidance ability of college students, which makes counselors not grasp the key points of work, and cannot carry out effective ideological guidance for college students.

\subsection{Insufficient political theory of ideological guidance}

The counselor team is of great significance, responsibility and glorious mission in the implementation of the basic task of moral education and promoting the healthy development of higher education. As the main attacker of ideological and political work, the leader of student management, and the backbone of student growth [7], the counselor should have a high degree of political responsibility, solid theoretical basis and other theoretical knowledge. At present, some counselors dare not stand up to dialogue, discrimination and refutation in front of the wrong social trend of thought, especially political thought, they have different degrees of loss, amnesia and other tendencies, such as vague understanding, blind obedience, self amnesia, and forget their responsibility and commitment. The political theory knowledge of counselors is insufficient, the ability of ideological guidance needs to be strengthened, and it is difficult to play the role of ideological guidance in college students.

\subsection{Insufficient professional ability of ideological guidance}

Counselors are organizers, implementers and directors of ideological and political education and daily management of college students. Starting from the particularity of counselor's position, counselor is the assistant of party committee work, teachers' teaching and students' learning [7], counselor plays an important role in ideological and political education. At present, some counselors' professional ability of ideological guidance is not enough, they lose their voice in front of difficult problems. Although counselors realize that they should make a voice, they can't take the initiative to set issues, and they have made a silent majority. At the same time, counselors also have self embarrassment phenomenon, such as the lack of the ability to reason, tell the truth, tell the story, and unable to be a 
storyteller. Meanwhile, they trap in embarrassment, and their leg weakness, brain loss of memory, voice loss and other practical difficulties.

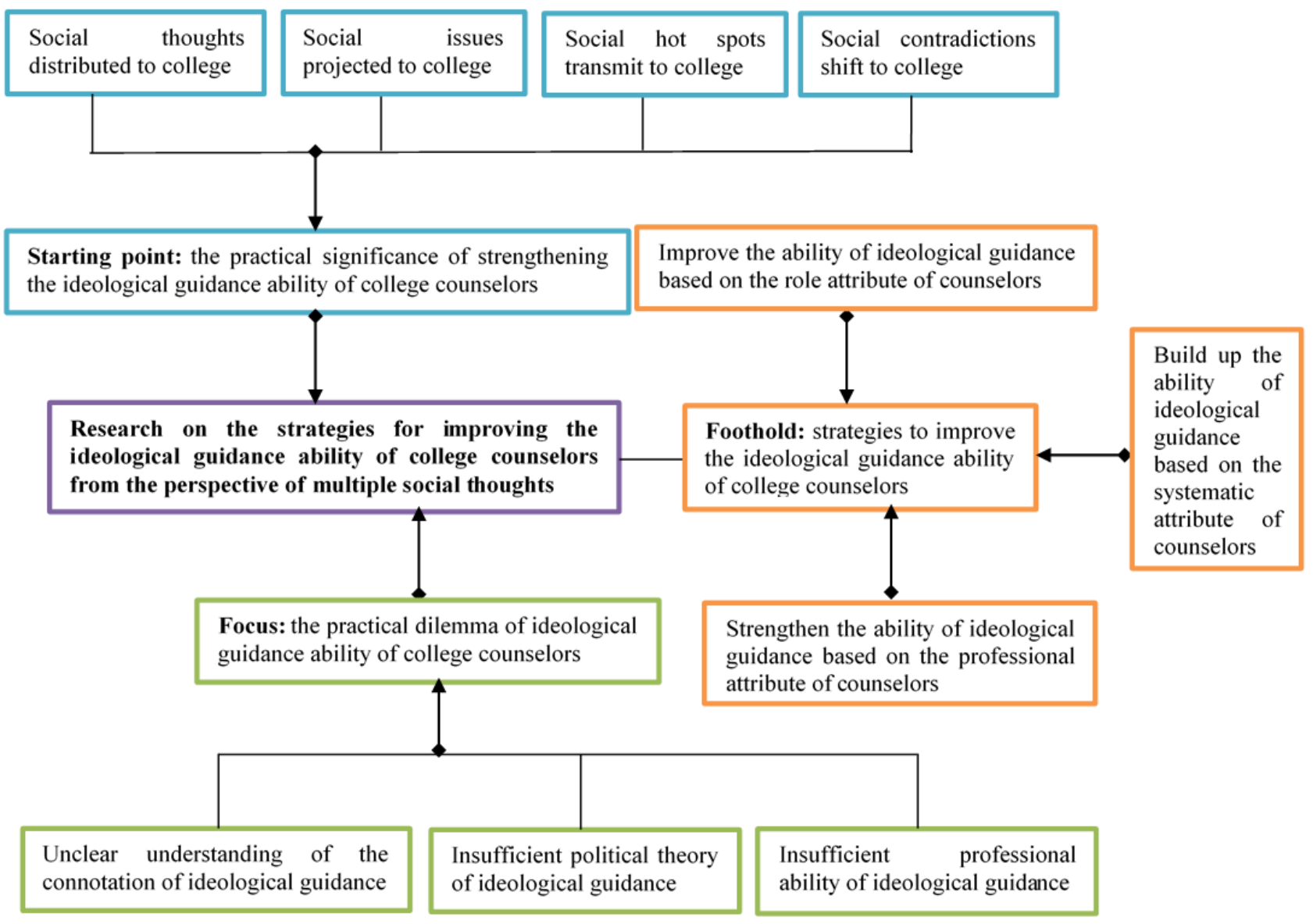

Figure 1 Strategies for Improving the Ideological Guidance Ability of College Counselors from the Perspective of Multiple Social Thoughts

\section{FOOTHOLD: STRATEGIES TO IMPROVE THE IDEOLOGICAL GUIDANCE ABILITY OF COLLEGE COUNSELORS}

\subsection{Improve the ability of ideological guidance based on the role attribute of counselors}

As the main organizer and implementer of the ideological and political education of college students, counselors play an important role in the ideological and political education of college students. The role attribute of college counselors requires that counselors have a strong ability of ideological guidance, and put forward higher requirements for counselors, counselors should play a leading role in college students' thinking, emotion, learning, behavior, employment and other aspects. From the perspective of working methods, counselors should deeply understand the "guidance" of counselors, they must strengthen the ideological guidance of students, guide students to correctly handle various relationships, solve problems encountered by students in learning, and guide students to make a scientific life plan. At the same time, the counselor should master the ideological situation and the law of change in the growth stage of college students, establish the growth files of students, make precise measures, improve the pertinence and effectiveness of ideological guidance of college students, be the ideological guide of college students, and help college students grow better.

\subsection{Strengthen the ability of ideological guidance based on the professional attribute of Counselors}

The decision of the Central Committee of the Communist Party of China on several major issues concerning the construction of a socialist harmonious society clearly points out that we should adhere to the socialist core value system to lead the social thoughts, respect differences, accommodate diversity, and maximize the formation of social thinking. The work of college counselors involves nine aspects, including ideological and political education, 


\section{REFERENCES}

party and league construction, academic guidance, daily affairs management, mental health education and consultation, network ideological and political education, crisis event response, career planning and employment guidance, theoretical and practical research, which makes the work of counselors have certain professionalism and technicality. Based on the professional attributes, counselors should integrate the socialist core value system into the students' work, actively publicize the party's ideas, carry out theoretical education, guide the campus hot spots, dredge the students' emotions, correct the wrong ideas, and lead the campus's public opinion, so as to give full play to the unique advantages of counselors in the ideological guidance of college students.

\subsection{Build up the ability of ideological guidance based on the systematic attribute of counselors}

The growth of college students is a systematic project that involves all aspects. College counselors should follow the law of ideological and political work, the law of teaching and educating students, the law of student growth, accurately understand the basic situation of students, and constantly summarize the characteristics and rules of ideological education. College counselors should make overall plan from the perspective of the overall development of students, systematically design the ideological and political education of college students, and do a good job of ideological guidance for college students. At the same time, college counselors should communicate and coordinate with colleges, schools, and other levels, strengthen the top-level design, consolidate the strength of various elements to participate in the ideological guidance of college students, and form a joint force of college students' ideological guidance and co-construction to promote college students' ideological maturity, independent personality, and normal behavior, counselors should strive to become students' life mentors and healthy friends.

\section{CONCLUSION}

It is of great significance to improve the ideological guidance ability of counselors for strengthening ideological and political education in colleges. This paper focuses on the analysis of the practical significance of strengthening the ideological guidance ability of college counselors from the perspective of multiple social thoughts, points out the practical difficulties in the ideological guidance ability of college counselors, and puts forward countermeasures to improve the ideological guidance ability of college counselors.
[1] Y. Wang. Social thought is an important content of ideological and political education in college [J]. Studies in Ideological Education, vol.1, pp. 23-25, 2016.

[2] D. T. Zou. How to release the positive energy of multiple social thoughts [J]. People's Tribune, vol.30, pp. 34-36, 2014.

[3] L. Chen, N. Shan. Trend of current domestic social thoughts [J]. People's Tribune, vol.6, pp. 12-15, 2018.

[4] B. Q. Wang. On the main factors affecting the development of social thoughts $[\mathrm{J}]$. The Party Building and Ideological Education in Schools, vol.17, pp. 4-6 + 43, 2010.

[5] L. C. Bai. Identification, Criticism and Cultivation: the role of college counselors in leading the hot social thoughts on the internet [J]. Mao Zedong Thought Study, vol.4, pp. 140-144, 2018.

[6] Q. H. Gan. Guidance of social hot and difficult issues and strengthen the research of ideological and political work [D]. Nanchang University, 2009.

[7] B. S. Chen. Strengthen the mission and responsibility to improve the construction level of counselor team [Z]. Ministry of Education, 2019. 